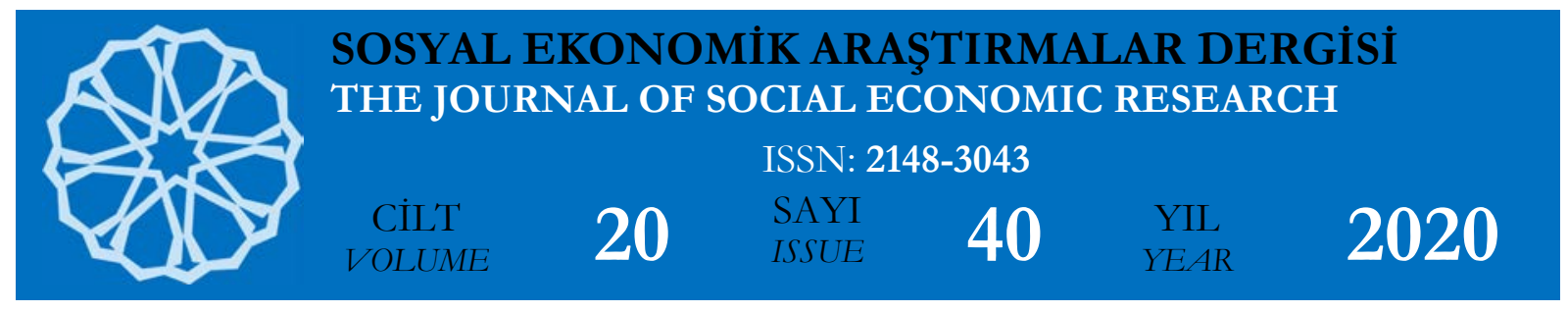

\title{
ÖN LİSANS ÖĞRENCİLERİNINN MUHASEBE DERSLERİNE YÖNELİK TUTUMLARI ÜZERİNE BİR ARAŞTIRMA
}

\section{A RESEARCH ON THE ATTITUDES OF ASSOCIATE DEGREE STUDENTS TOWARDS THE ACCOUNTING COURSES}

İbrahim APAKa,

\begin{abstract}
a Dr. Öğretim Üyesi, Aksaray Üniversitesi, Sosyal Bilimler MYO, Muhasebe ve Vergi Uygulamaları Bölümü ORCID: 0000-0002-54040361

E-posta: apakibrahim@gmail.com
\end{abstract}

Makale Türü

Araştırma Makalesi

Makale Geliş Tarihi 30.04.2020

Makale Kabul Tarihi 26.10.2020

\section{ÖZ}

Amaç - Ön lisans öğrencilerinin muhasebe derslerine yönelik tutumlarının tespit edilmesidir. Yöntem - Aksaray Üniversitesi, Sosyal Bilimler Meslek Yüksekokulu, Muhasebe ve Vergi Uygulamaları bölümü öğrencilerine anket uygulanarak elde edilen 117 veri SPSS 20.0 programında analiz edilmiştir.

Bulgular - Öğrencilerin muhasebe derslerine yönelik tutumu olumlu yönde ortanın üzerindedir. Ayrıca araştırmada öğrencilerin demografik özellikleri ile muhasebe derslerine yönelik tutumları arasında farkların tespit edilmesi için analizler gerçekleştirilmiştir. Öğrencinin bulunduğu sınıf ile muhasebe derslerine ve muhasebe mesleğine yönelik tutumu farklılaşmaktadır.

Sonuç - Üniversite öncesinde muhasebe dersi almış olan öğrencilerin muhasebe derslerine yönelik tutum ortalamaları daha olumludur. Ayrıca okuduğu bölümü isteyerek tercih eden ögrencilerin muhasebe derslerine yönelik tutumları olumlu yönde daha yüksektir.

Anahtar Kelimeler: Muhasebe, Tutum, Muhasebe eğitimi.

JEL Kodlar1: M40, M41

\begin{abstract}
Purpose - Determining the attitudes of associate degree students towards the accounting courses.

Methodology - A questionnaire was applied to the students of the Accounting and Tax Applications Department, Vocational School of Social Sciences, Aksaray University and 117 questionnaire data were analyzed in the SPSS 20.0 program.

Findings - The students' attitudes towards the accounting courses is positive and above the medium level. Also, analyzes are conducted to determine the differences between the demographic characteristics of students and their attitudes towards the accounting courses. The attitudes of the students towards the accounting classes and accounting profession differs by the first year, second year, and others.

Conclusions - The attitudes of the students who have taken an accounting course before university are more positive and the students that attend the department willingly have a more positive attitudes towards the accounting courses.

Keywords: Accounting, Attitudes, Accounting education.

JEL Codes: M40, M41
\end{abstract}

\section{GİRİŞ}

Muhasebeye ilişkin alg1 değerlendirildiğinde öğrencilerin alg1sı çoğunlukla olumsuz yönündedir (Malthus \& Fowler, 2009; Akpınar \& Yıldız, 2018; Ertuğrul \& Özdemir, 2014). Genellikle öğrenciler muhasebenin tek düze ve sıkıcı olduğu düşüncesinden yola çıkarak bu olumsuz algıya sahip olmaktadır (Wells, 2015). Söz konusu bu yargıların değiştirilebilmesi için öğrencilerin muhasebe tutumlarının tespit edilmesi ve bu tutuma yol açan etkenlerin ortadan kaldırılabilmesi için çözüm önerilerinin getirilmesi gerekmektedir. 
Muhasebeye yönelik tutumun değiştirilebilmesi için özellikle öğrencilerin muhasebe ile ilk kez karşılaştıkları derslere yönelik çalışmalar artırılmalıdır. Geiger ve Ogilby (2000) muhasebe tutumunda öğreticinin tavır ve yaklaşımının özellikle muhasebeye yönelik ilk (temel) derslerde öğrencilerin muhasebe alanında ilerleyip ilerlemeyeceğini etkilediğini ifade etmektedir. Başka bir ifadeyle öğrencilerin muhasebe ile tanıştığı ders - ki çoğunlukla bu genel (finansal) muhasebe dersidir - muhasebeye ilişkin tutumları şekillendirmektedirler. Bu noktada öğreticinin izlediği metodoloji, akademik bilgi düzeyi, kullandığı materyaller ve fiziki ortam gibi değişkenler öğrencinin muhasebe alanında ilerleme kararında etkili olabilmektedir.

Muhasebe tutumu üzerine yapılan araştırmalarda öğrencilerin muhasebe tutumu üzerinde en fazla öğretici (Góis \& Brás, 2013; Geiger \& Ogilby, 2000; Kutlu \& Öztürk, 2018; Kız1l \& Gencer, 2016) faktörünün etkili olduğunu göstermektedir. Marriott \& Marriott (2003) öğrencilerin muhasebe eğitimi sonrasında, muhasebe eğitimi öncesine kıyasla daha olumsuz muhasebe algisına/tutumuna sahip olduklarını bulgulamışlardır. $\mathrm{Bu}$ açıdan verilen muhasebe eğitimi öğrencilerde muhasebeye ve muhasebe mesleğine olumsuz yönde etki etmektedir. Öte yandan Utku ve Erol (2015) muhasebe eğitimi alan öğrencilerin muhasebe algılarınıın dönem başından dönem sonuna (bazı alt boyutlar hariç) olumlu yönde geliştiği bulgusuna ulaşmışlardır. Benzer şekilde Aygün ve Gerekan (2012) çalışmalarında öğrencilerin muhasebe algısının dönem başından dönem sonuna doğru olumlu yönde değiştiği bulgusunu belirtmektedirler. Bunun yanı sıra öğrencinin cinsiyetinin de muhasebe tutumunu etkilediği yönünde bulgulara rastlanmaktadır (Byrne \& Willis, 2005; Góis \& Brás, 2013; Aksu \& Oral, 2017).

Bu çalışmada muhasebe eğitimi alan ön lisans öğrencilerinin muhasebe derslerine yönelik tutumlarının belirlenmesine yönelik bir araştırma yapılmıştır. Araştırmada anket ile elde edilen veriler analiz edilmiştir. Ayrıca öğrencilerin demografik özellikleri ve muhasebe derslerine yönelik tutumları arasında farklılıkların olup olmadığının belirlenmesi amacıyla da analizler gerçekleştirilmiştir. Analizler sonucu elde edilen bulgular literatürdeki benzer araştırmalarda elde edilen bulgularla karşılaştırmalı olarak yorumlanmıştır.

\section{LİTERATÜR TARAMASI}

Araştırma kapsamında gerçekleştirilen literatür taramasıyla muhasebe eğitimi alan öğrencilerle gerçekleştirilen araştırmalar muhasebeye yönelik alg1-tutum, muhasebe eğitimi sürecinin etkileri ve demografik özellikler kapsamında gerçekleştirilmiştir. Araştırma anketinde ve bulguların yorumlanmasında literatürden yararlanılmıştır.

Geiger ve Ogilby (2000) yapmış oldukları çalışmada muhasebe alanında öğrencilerin aldığı ilk ders ile birlikte öğrencilerin muhasebe algisı ve muhasebe alanında uzmanlaşmayı isteyip istememeleri üzerindeki etkisini incelemişlerdir. Araştırmada iki farklı üniversitedeki muhasebe alanında olan ve olmayan öğrencilere $(n=331)$ finansal muhasebeye giriş dersi öncesinde ve sonrasında anket uygulanmıştır. Dönem başında muhasebe alanındaki öğrencilerin algıları diğer öğrencilere kıyasla daha biraz daha yüksek olmakla birlikte genel olarak olumlu yöndeyken; dönem sonunda her iki gruptaki öğrencilerin tutumları daha az olumlu düzeye indiği bulgulanmıştır. Ayrıca öğrencilerin muhasebe alanında uzmanlaşma tercihinde ve muhasebeye yönelik tutumlarında öğreticinin önemli rol oynadığı bulgulanmıştır.

Malthus ve Fowler (2009) yapmış oldukları çalışmada Yeni Zelanda'da muhasebe öğrencilerinin muhasebe algılarının tespit edilmesi amaçlanmaktadır. Çalışma kapsamında öğrenciler, öğreticiler ve öğrencilerin kariyer tercihlerinde etkili olan kişilerle mülakatlar ve odak grup görüşmeleri gerçekleştirilmiştir. Öğrencilerin muhasebe eğitiminin başında muhasebeyi sıkıcı buldukları ancak eğitimin sonunda muhasebe ve muhasebe mesleği ile ilgili daha olumlu hale geldikleri bulgusuna ulaşılmıştır. Öğreticilerin muhasebeye yönelik olumlu tutumları olmasına karşın kariyer planlama işi ile ilgilenen kişilerin diğer mesleklere göre hala muhasebenin sıkıcı olduğuna yönelik fikirlere sahip olduğu sonucuna ulaşılmıştır.

Góis ve Brás (2013) yapmış oldukları çalısmada Bologna süreci sonrasında Portekiz'de faaliyet gösteren iki farklı yükseköğrenim kurumunda yüksek lisans öğrencilerinin muhasebe alg1larını incelemişlerdir. Dönem başında ve sonunda uygulanan anket sonuçlarına göre muhasebe dersine yönelik motivasyonları dönem başında oldukça yüksek olan öğrencilerin dönem sonunda algılarının olumsuza döndüğü bulgusuna ulaşılmışır.

Çakır, Canbaz ve Gümüş (2014) yapmış oldukları çalışmada meslek yüksekokulu öğrencilerinin muhasebe algisı ve beklentilerini incelemişlerdir. Araştırma Uzunköprü Meslek Yüksekokulu’ndaki öğrenciler ( $\mathrm{n}=258)$ ile gerçekleştirilmiştir. Öğrencilerin panel, konferans gibi etkinliklerle eğitimlerinin desteklenmesi 
beklentisinde olduğu; meslek yüksekokulundan önce muhasebe dersi alan öğrencilerin derslere daha iyi adapte olduklarını, ancak daha önce muhasebe dersi almayan öğrencilerin muhasebe alg1larını olumsuz yönde etkilediği bulgusuna ulaşılmıştır.

Tuğay (2014) yapmış olduğu çalışmada muhasebe dersi alan öğrencilerin muhasebe algıları, muhasebe meslek algılarını ve öğretim elemanlarından beklentilerini incelemiştir. Çalışmada Mehmet Akif Ersoy Üniversitesi, İktisadi ve İdari Bilimler Fakültesi ve üniversiteye bağlı Meslek Yüksekokullarında muhasebe dersi alan öğrencilere $(n=896)$ anket uygulanmıştır. Araştırmada öğrencilerin çoğunluğunun daha önce muhasebe dersi almadığı, öğrencilerin muhasebe derslerinde orta düzeyde zorlandığ1 ve öğrencilerin çoğunluğunun muhasebe mesleğini yapmak istemediği sonucuna ulaşılmıstır.

Wells (2015) yapmış olduğu çalışmada Yeni Zelanda'da lise öğrencilerinin muhasebe algısının ve bu algının oluşumunun nasıl ve neden olduğunu ele almaktadır. Anket uygulaması ve odak grup görüssmeleri gerçekleştirilen öğrencilerin bir kısmı muhasebe programı öğrencilerden seçilirken bir kısmı ise muhasebe programından olmayan öğrencilerden seçilmiştir. Araştırma bulgularına göre muhasebe programı öğrencisi olan öğrencilerin algısı muhasebe programı öğrencisi olmayan öğrencilere kıyasla daha olumludur.

Utku ve Erol (2015) yapmış oldukları çalışmada muhasebe eğitimi alan öğrencilerin bir dönem sonunda muhasebe algilarındaki değişimi incelenmişlerdir. Akdeniz Üniversitesi, İktisadi ve İdari Bilimler Fakültesi, İşletme ve İktisat bölümlerindeki öğrencilere $(\mathrm{n}=164)$ anket uygulanmıştır. Elde edilen bulgulara göre öğrencilerin muhasebe algıları belirli alt boyutlar dışında genel olarak olumlu yönde gelişmiştir.

Costa vd. (2015) yapmış oldukları çalışmada Brezilya'da bir devlet üniversitesindeki muhasebe, işletme ve iktisat bölümü öğrencilerinin muhasebeye giriş derslerine ilişkin algılarını incelemişlerdir. Öğrencilere $(n=145)$ anket uygulanarak elde edilen veriler analiz edilmiştir. Elde edilen bulgulara göre muhasebe bölümü öğrencileri diğer bölümlerdeki öğrencilere oranla daha iyimser olmakla birlikte öğrenciler genel olarak olumlu muhasebe algisina sahiptir.

Kandemir, Kardeş ve Baykut (2016) yapmış oldukları çalışmada Meslek Yüksekokulu öğrencilerinin muhasebe eğitimine bakış açılarını ele almışlardır. Araştırma Afyon Kocatepe Üniversitesi'ne bağlı Meslek Yüksekokulu öğrencileri $(n=272)$ ile gerçekleştirilmiştir. Analiz sonucu elde edilen bulguya göre öğrencilerin $\% 52$ 'sinin muhasebeye bakış açıları olumlu yöndedir.

Coşkun, Kır ve Özbay (2017) yapmış oldukları çalışmada öğrencilerin muhasebe eğitiminden beklentileri ve muhasebe eğitimine ilişkin görüşleri incelenmiştir. Araştırma Manisa Celal Bayar Üniversitesi, Ahmetli Meslek Yüksekokulu, Muhasebe ve Vergi Uygulamaları Bölümü öğrencileri (n=276) ile gerçekleştirilmiştir. Çalışmada okuduğu sınıf ile beklenti arasında fark olduğu bulgusuna ulaş1lırken; cinsiyet, lise türü ve tercih sırası ile beklenti arasında istatistiki olarak anlamlı fark bulunamamıştır.

Aksu ve Oral (2017) yapmış oldukları çalışmada öğrencilerin muhasebe derslerine yönelik algı ve başarı durumlarını incelemişlerdir. Araştırma İnönü Üniversitesi, İktisadi ve İdari Bilimler Fakültesi, Ekonometri ve İktisat Bölümlerindeki öğrencilerle $(n=166)$ gerçekleştirilmiştir. Anket formu kullanılan çalışmada elde edilen verilerin analizine göre cinsiyet ile muhasebe algısı arasında istatistiki olarak anlamlı fark bulunmuştur. Ayrıca derslerin zorluğu algısı ile bölümler arasında farklilıklar olduğu bulgusuna ulaşılmışır.

Gör (2017) yapmış olduğu çalışmada farklı bölümlerdeki öğrencilerin finansal muhasebe dersine yönelik algılarını etkileyen faktörleri ele almıştır. Araştırma Çankırı Karatekin Üniversitesi, İşletme, İktisat, Uluslararası Ticaret, Bankacilık ve Finans bölümlerindeki öğrenciler $(n=356)$ ile gerçekleştirilmiştir. Araştırma bulgularına göre demografik özellikler muhasebe algısını etkilemektedir.

Akpınar ve Yıldız (2018) yapmış oldukları çalışmada muhasebe eğitimi alan öğrencilerin muhasebe algılarını metaforlar üzerinden incelemişlerdir. Sakarya Üniversitesi, İşletme, Sağlık Yönetimi, Finansal Ekonometri ve Yönetim Bilişim Sistemleri bölümlerindeki öğrenciler $(n=271)$ ile gerçekleştirilen araştırmada öğrencilere muhasebeyi renk, hayvan, besin türü, mevsim, oyun, çiçek ve eşya olarak tanımlamaları istenmiştir. Elde edilen bulgulara göre öne çıan muhasebe algısı zor, sıkıc1, karmaşık, gerekli, faydalı, önemli ve heyecan verici şeklindedir. Ayrıca öğrencilerin muhasebeyi tanımlamada en fazla kullandıkları metaforlar siyah, aslan (kaplan), sebze türü, kış, saklambaç, kaktüs ve hesap makinesi" olarak bulgulanmıştır. 


\section{ARAŞTIRMA}

Araştırmanın amacı Aksaray Üniversitesi, Sosyal Bilimler Meslek Yüksekokulu, Muhasebe ve Vergi Uygulamaları Bölümü öğrencilerinin muhasebe derslerine yönelik tutumlarının tespit edilmesidir. Ayrıca araştırmada demografik özellikler ile muhasebe derslerine yönelik tutuma ilişkin farkllıkların tespit edilmesi amaçlanmaktadır. Muhasebe ve Vergi Uygulamaları Bölümünde öğrenciler dört dönemde zorunlu ve seçmeli türde olmak üzere muhasebe alanında Genel Muhasebe, Dönem Sonu Envanter İşlemleri, Maliyet Muhasebesi, Bilgisayarlı Muhasebe I-II, Şirketler Muhasebesi, Muhasebe Denetimi derslerini almaktadırlar (https://obs.aksaray.edu.tr/oibs/bologna, 2019).

\subsection{Araştırmanın Yöntemi}

Muhasebe ve Vergi Uygulamaları Bölümündeki normal öğretim ve ikinci öğretim öğrencilerinin katılımıyla gerçekleştirilen araştırmada öğrencilere 2019-2020 güz dönemi ortasında anket uygulanarak veri toplanmış ve elde edilen veriler SPSS 20.0 programı ile analiz edilmiştir. Araştırmada kullanılan anket formu iki kısımdan oluşmaktadır. Birinci kısımda katılımcının demografik özelliklerine ilişkin sorulara yer verilmektedir. İkinci kısımda ise Çelik ve Serinkan'ın (2011) çalışmalarında kullandıkları ankette 5'li likert ölçeğine göre (1-Kesinlikle katılmıyorum, 5-Kesinlikle katıllyorum) düzenledikleri, geçerlilik ve güvenilirlik

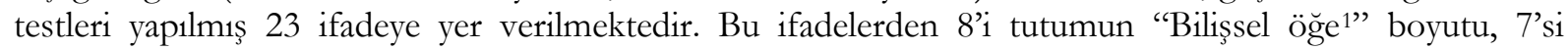
"Duyuşsal öğe2" boyutu ve diğer 8'i ise "Davranışsal öğe ${ }^{3 "}$ " boyutu ile ilgilidir. Çalışmada tutumla ilgili olarak gerçekleştirilen analiz ve yorumlamalar genel tutum ve tutumun öğeleri kapsamında gerçekleştirilmiştir. Bu ifadelerin yanı sıra katılımcıların muhasebe alanında ilerleme yönelimlerinin tespit edilmesi amacıyla üç ifadeye daha yer verilmiştir. Araştırma kapsamında araştırmaya katılmak isteyen öğrencilerden kullanılabilir 117 anket elde edilmiştir. Bu sayı bölümde kayıtlı toplam öğrenci sayısının yaklaşık \%44’üne tekabül etmektedir.

Veri analizinde öğrencilerin demografik özelliklerine ve tutum ifadelerine ilişkin frekans analizlerine yer verilmektedir. Demografik özellikler ve muhasebe tutumları farklarının tespiti için analizler yapılmadan önce verilerin normal dağılıp dağılmadığının tespit edilmesi için "Skewness" ve "Kurtosis" değerleri kontrol edilmiştir. "Skewness" ve "Kurtosis" değerlerinin $-2,00$ ile $+2,00$ aralığında olmas 1 halinde verilerin normal dağıldığ kabul edilmektedir (George \& Mallery, 2010; Gravetter \& Wallnau, 2014). Verilerin normal dağıldığ1 tespit edildikten sonra demografik özellikler değişkenleri için fark testlerinde One-way ANOVA ve Independent Samples T-testi kullanılmıştır.

\subsection{Analiz ve Bulgular}

Araştırmaya katılan öğrencilere ilişkin cinsiyet, okuduğu sınıf, mezun olduğu lise türü, normal öğretim-ikinci ögretim, tercih sırası, tercih istek durumu, muhasebe dersleri ile daha önce karşılaşma durumu ve öğrencinin istihdam durumuna ait sayısal bilgilere Tablo 1'de yer verilmektedir.

Tablo 1. Demografik Özellikler

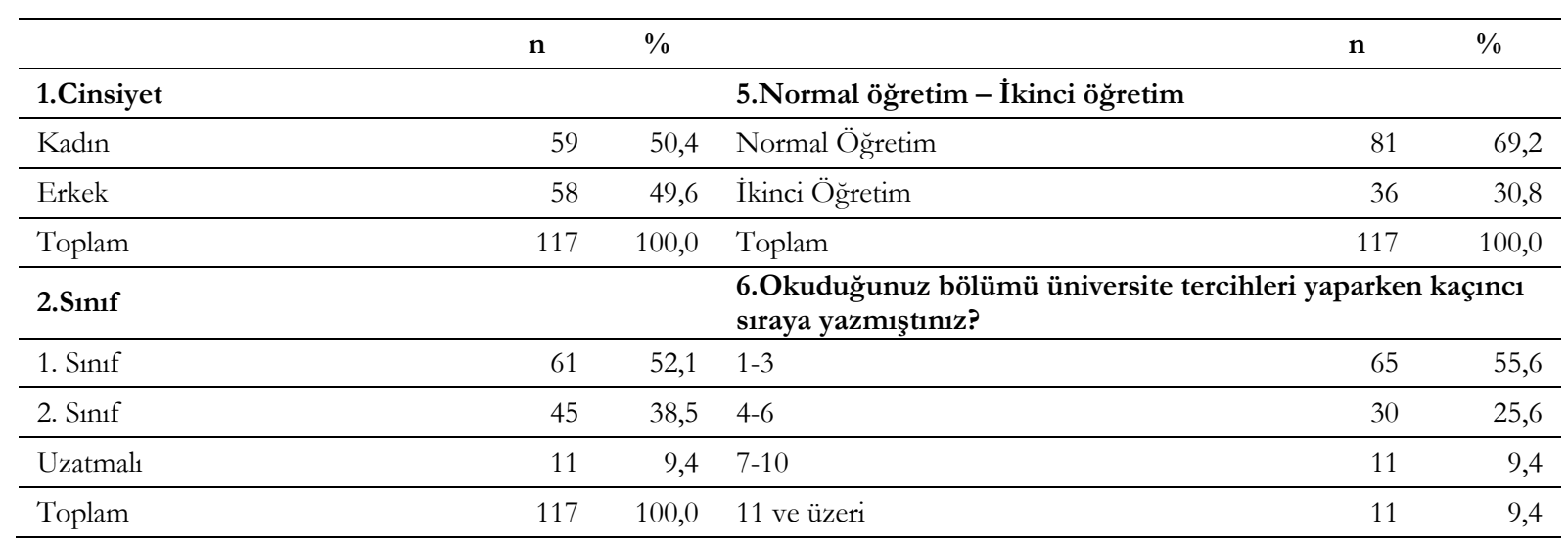

1 Bilissel öğe: Görüs, bilgi ve inançlardir.

2 Duyussal öğe: Sevme, nefret etme ve korkma gibi duygularder.

${ }^{3}$ Davranıssal öğe: Uzak durma ve yakmlaşma gibi dauranıslardır. 


\begin{tabular}{|c|c|c|c|c|c|}
\hline & & & Toplam & 117 & 100,0 \\
\hline \multicolumn{3}{|l|}{ 3.Mezun olunan lise türü } & \multicolumn{3}{|c|}{ 7.Aksaray üniversitesinden önce muhasebe dersi aldınız mı? } \\
\hline Genel Lise & 11 & 9,4 & Evet & 31 & 26,5 \\
\hline Anadolu Lisesi & 41 & 35,0 & Hayır & 86 & 73,5 \\
\hline Ticaret Lisesi & 12 & 10,3 & Toplam & 117 & 100,0 \\
\hline Mesleki ve Teknik Anadolu Lisesi & 34 & 29,1 & \multicolumn{3}{|c|}{ 8.Okuduğunuz bölümü isteyerek mi tercih ettiniz? } \\
\hline Temel Lise & 6 & 5,1 & Evet & 80 & 68,4 \\
\hline İmam Hatip Lisesi & 6 & 5,1 & Hayır & 37 & 31,6 \\
\hline Diğer & 7 & 6,0 & Toplam & 117 & 100,0 \\
\hline Toplam & 117 & 100,0 & & & \\
\hline \multicolumn{3}{|c|}{ 4.Şuanda her hangi bir işte çalışıor musunuz? } & \multicolumn{3}{|c|}{$\begin{array}{l}\text { 9.Çalıştığınız işte doğrudan muhasebe ile temas halinde } \\
\text { misiniz? }\end{array}$} \\
\hline Evet & 28 & 23,9 & Evet & 11 & 9,4 \\
\hline Hayır & 89 & 76,1 & Hayır & 17 & 14,5 \\
\hline Toplam & 117 & 100,0 & Toplam & 28 & 23,9 \\
\hline
\end{tabular}

Tablo 1'de yer alan bilgilere göre araştırmaya katılan öğrencilerin cinsiyet dağlımı 59 kadın, 58 erkek şeklindedir. Öğrencilerin \%52,1’i 1. sınıf öğrencisi ve \%69,2'si normal öğretimde yer almaktadır. \%35’i anadolu liselerinden mezun olmuş ve araştırmaya katılan bütün öğrencilerin \% $\% 3,5$ ’ daha önce hiç muhasebe dersi almamışlardır. Öğrencilerin bölüm tercih sırasına bakıldığında \%81,2'si okuduğu bölüme ilk 6 tercihleri arasında yer vermiş ve öğrencilerin \%68,4'ü bölümü isteyerek tercih etmişlerdir. Öğrencilerin \%23,9’u bir işte çalışmakta ve öğrencilerin \%9,4'ü çalıştığı yerde muhasebe ile temas halindedir. Araștırma analizlerinden önce verilerin güvenilirliğinin tespit edilmesi amacıyla güvenilirlik testleri gerçekleştirilmiş ve elde edilen Cronbach's Alpha değerlerine Tablo 2'de yer verilmiştir.

Tablo 2. Güvenirlilik Testi Sonuçları

\begin{tabular}{lcc}
\hline & Cronbach's Alpha & Madde sayıs \\
\hline Genel tutum &, 955 & 23 \\
\hline Bilişsel öğe &, 831 & 8 \\
\hline Duyuşsal öğe &, 927 & 7 \\
\hline Davranışsal öğe &, 929 & 8 \\
\hline Meslek tercih &, 908 & 3 \\
\hline
\end{tabular}

Sosyal bilimlerdeki araştırmalarda Cronbach's Alpha değerinin 0,60 ve üzerinde olması durumunda verilerin analiz için güvenilir olduğu kabul edilmektedir (Loewenthal, 2004). Araştırmanın anketinde yer alan ifadelere genel tutum ve tutumun alt öğeleri bazında uygulanan güvenilirlik analizi sonuçlarının yer aldığı Tablo 2'deki Cronbach's Alpha değerlerine göre verilerin analiz yapmak için güvenilirdir. Öğrencilerin araştırma anketinden yer alan ifadelere (1-Kesinlikle katılmiyorum - 5-Kesinlikle katıllyorum) verdikleri yanıtların ortalamaları genel tutum ve tutum alt boyutları bazında Tablo 3'te yer almaktadır.

Tablo 3. Frekans Analizi Sonuçları

\begin{tabular}{|c|c|c|c|c|}
\hline : & İfade & Ort. & $\begin{array}{l}\text { Std. } \\
\text { Sapma }\end{array}$ & $\begin{array}{l}\text { Genel } \\
\text { Ort. }\end{array}$ \\
\hline \multirow{8}{*}{ 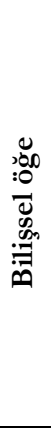 } & 1.Muhasebe zevklidir ve beni motive eder & 3,39 & 1,144 & \multirow{8}{*}{3,655} \\
\hline & 2.Muhasebe dersi seçtiğim bölüm için gereklidir & 3,97 & 1,228 & \\
\hline & 3.Muhasebe alanında iddialıyım & 3,09 & 1,156 & \\
\hline & 4.Muhasebe öğrenmek zahmete değer & 3,73 & 1,111 & \\
\hline & 5.Muhasebeyi öğrenmek iş imkânlarımı artırır & 4,01 & 1,030 & \\
\hline & 6.Muhasebe dersinde öğretilenler çalışma yaşamı için gereklidir & 3,79 & 1,063 & \\
\hline & 7.Muhasebeyi hayatım boyunca birçok yerde kullanacağım & 3,53 & 1,134 & \\
\hline & $\begin{array}{l}\text { 8.Muhasebe dersi bölümden mezun olduktan sonra çalışmayı düşündüğüm meslek için } \\
\text { gereklidir }\end{array}$ & 3,73 & 1,304 & \\
\hline
\end{tabular}




\begin{tabular}{|c|c|c|c|c|}
\hline \multirow{7}{*}{ 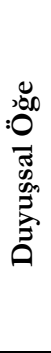 } & 9.Muhasebe derslerini severim & 3,55 & 1,141 & \multirow{7}{*}{3,444} \\
\hline & 10.Muhasebe çalışmayı isterim & 3,55 & 1,283 & \\
\hline & 11.Muhasebe sevdiğim dersler arasındadır & 3,52 & 1,164 & \\
\hline & 12.Muhasebe derslerinden zevk alırım & 3,56 & 1,109 & \\
\hline & 13.Genelde okulda muhasebe çalışmayı severim & 3,16 & 1,098 & \\
\hline & 14.Muhasebe çalışırken kaygılı olmam & 3,09 & 1,160 & \\
\hline & 15.Muhasebe becerilerimi geliştirmeyi ve bu konuda daha çok çalışmayı isterim & 3,68 & 1,142 & \\
\hline \multirow{9}{*}{ 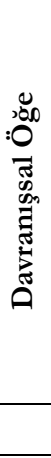 } & 16.Muhasebe derslerini çalışırken çok rahat ve sakinim & 3,26 & 1,269 & \multirow{8}{*}{3,360} \\
\hline & 17.Muhasebe dersleri ilgili ödevlerimi yaparken panik olmam & 3,38 & 1,231 & \\
\hline & 18.Daha fazla muhasebe bilgisi edinmeye çalışırım & 3,70 & 1,053 & \\
\hline & 19.Muhasebe çalışmaya başlayınca bırakamamam & 3,04 & 1,206 & \\
\hline & 20.Muhasebeyle ilgili problemleri çözmeye çalışırım & 3,53 & 1,095 & \\
\hline & 21.Yeni bir Muhasebe problemiyle uğraşırken kendimi rahat hissederim & 3,05 & 1,136 & \\
\hline & 22.Derste çözümü yarım kalan muhasebe sorularılya uğraşmak bana zevk verir & 3,22 & 1,260 & \\
\hline & 23.Muhasebe derslerindeki konuların işleniş yöntemlerini seviyorum & 3,69 & 1,156 & \\
\hline & \multicolumn{3}{|c|}{ Muhasebe dersleri genel tutum ortalama } & 3,490 \\
\hline \multirow{3}{*}{$\frac{\frac{y}{0}}{\frac{0}{d}}$} & 24.Mezun olduktan sonra herhangi bir işletmede muhasebe departmanında çalışmak isterim & 3,56 & 1,329 & \multirow{3}{*}{3,460} \\
\hline & 25.Okuduğum programdan mezun olduktan sonra aynı alanda devam etmek isterim. & 3,40 & 1,327 & \\
\hline & $\begin{array}{l}\text { 26.Mezun olduktan sonra eğitimime devam edip Serbest Muhasebeci ve Mali Müşavir olmak } \\
\text { isterim. }\end{array}$ & 3,42 & 1,385 & \\
\hline
\end{tabular}

Tablo 3'te yer alan bilgilere göre öğrencilerin muhasebe derslerine yönelik genel tutum ortalaması 3,49'dur. 1-5 aralığında ele alındığında bu sonuç öğrencilerin olumlu yönde orta üzeri bir tutuma sahip olduklarını göstermektedir. Tutumun alt öğeleri açısından bakıldığında ortalamalar bilişsel öğede 3,655, duyuşsal öğede 3,444 ve davranışsal öğede ise 3,360'tır. Öğrencilerin muhasebe derslerine yönelik tutumlarında bilişsel öğe ortalaması en yüksek, davranışsal öğe ortalaması ise en düşük olan öğe olarak karşımıza çıkmaktadır. Meslek tercihi açısından değerlendirildiğinde ise öğrenciler muhasebe mesleğini yapma isteği ortalaması 3,460'tır. Çoğunluk mezun olduktan sonra muhasebe alanında ilerlemek yerine herhangi bir işletmede muhasebe departmanında çalışmayı daha uygun görmektedir.

Genel tutum ortalamalarına bakıldığında öğrencilerin en çok katıldığı ifade "5.Mubasebeyi ögrenmek is imkânlarmı artırı" ifadesidir. Bu ifade öğrencilerin muhasebe derslerini öğrendiklerinde mezun olduktan sonra profesyonel hayatta iş imkânlarını artırabileceğini düşündüklerini göstermektedir. En düşük ortalamaya sahip ifade ise "19.Muhasebe calısmaya başlaynnca birakamamam" ifadesidir. Bu ifade muhasebeye yönelik literatürde çokça değinilen "muhasebe sıkıcıdır" düşüncesini destekler niteliktedir.

Tutumun alt öğeleri açısından değerlendirildiğinde öne çıkan ifadeler sırasıyla "5.Mubasebeyi ögrenmek iş imkânlarmı artırı", "15.Muhasebe becerilerimi gelistirmeyi ve bu konuda daba çok çalıșmayı isterim" ve "18.Daha fazla muhasebe bilgisi edinmeye çalşıırm" ifadeleridir. Ortalamalar bu üç ifade açısından değerlendirildiğinde öğrencilerin muhasebe derslerinin kendilerine kazandıracağı avantajların farkında olduklarını ve bu doğrultuda daha çok çalışmaya hevesli olduklarını söylemek mümkündür.

Bilişsel öğe kapsamında yer alan ifadelerde en yüksek ortalamaya sahip ifade "5.Mubasebeyi ögrenmek iş imkânlarmı artırr" ifadesi; en düşük ortalamaya sahip ifade ise "3.Muhasebe alanında iddialyyım" ifadesidir. Bu durumu, öğrenciler kariyer firsatı olması bakımında muhasebenin gelecekte kendileri için fayda sağlayacağının farkındadırlar ancak henüz yeterli bilgi donanımına sahip değillerdir şeklinde yorumlamak mümkündür.

Duyuşsal öğe kapsamında yer alan ifadelerden en yüksek ortalamaya sahip ifade "15.Muhasebe becerilerimi gelistirmeyi ve bu konuda daba çok çalşsmayı isterim" ifadesi; en düşük ortalamaya sahip ifade ise "14.Mubasebe çalşsırken kaygzl olmam" ifadesidir. Bu durumu, öğrencilerin kendilerini muhasebe alanında geliştirme konusunda istekli oldukları ancak muhasebeye yönelik olumsuz ön yargıların, muhasebenin sayısal içerikli olmasının ve hukuki yönlerinin öğrenciler üzerinde kaygiya neden olduğu şeklinde değerlendirmek mümkündür. 
Davranışsal öğe kapsamında yer alan ifadelerden en yüksek ortalamaya sahip ifade "18.Daba fazla mubasebe bilgisi edinmeye calışırm" ifadesi; en düşük ortalamaya sahip ifade ise "19.Muhasebe çalşsmaya bașlaynnca brrakamamam" ifadesidir. Bu durumu öğrencilerin muhasebeye yönelik kendilerini geliştirmeye açık oldukları ancak muhasebenin yer yer birbirini tekrar eden işlemlerden oluşan bir yapıda olması nedeniyle ders çalışırken uzun süreler boyunca odaklanmada zorluk çektikleri şeklinde yorumlamak mümkündür.

Tutumun üç boyutu ve bulgular ele alındığında öğrencilerin muhasebeye yönelik tutumlarını şekillendiren gruplara ve özellikle de öğreticilere sorumluluklar düşmektedir. Genel olarak el alındığında öğrenciler muhasebenin sunduğu potansiyel firsatların farkında oldukları ancak derslerin veriliş biçimleri, kullanılan materyaller ve kariyer fırsatlarının aktarılması ile ilgili çeşitli geliştirmelerle öğrencilere daha yararlı olunabileceğini söylemek mümkündür.

Araştırmaya katılan öğrencilerin muhasebe derslerine yönelik tutumlarının demografik özelliklere göre farklarının test edilmesi amacıyla analizler gerçekleştirilmiştir. Cinsiyet, normal öğretim-ikinci öğretim durumu, daha önce muhasebe dersi alma durumu, tercih isteği, çalışma durumu ve muhasebe derslerine yönelik tutum için Independent Samples T-testi uygulanmıştır. Okuduğu sınıf, mezun olunan lise türü, tercih sırası ve muhasebe derslerine yönelik tutum için One-way ANOVA kullanılmıştır. Fark testlerinin sonuçlarına Tablo 4'te yer verilmektedir.

Tablo 4. Demografik Özellikler ve Muhasebe Tutumu Analiz Test Sonuçları

\begin{tabular}{|c|c|c|c|c|c|c|}
\hline $\begin{array}{c}\text { Tutum, Tutum Öğgeleri } \\
\text { ve Meslek Tercihi }\end{array}$ & & Değişkenler & $\mathbf{N}$ & Ort. & $\begin{array}{l}\text { Standart } \\
\text { Sapma }\end{array}$ & $\begin{array}{c}\text { F ve Sig. } \\
\text { (Farkın kaynağı) }\end{array}$ \\
\hline \multirow{4}{*}{ Genel Tutum } & \multirow{20}{*}{ 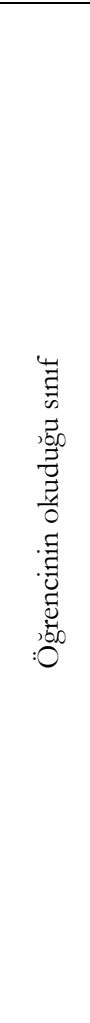 } & 1. Sinif & 61 & 3,6664 & ,85025 & \multirow{4}{*}{$\begin{array}{r}\mathrm{F}=3,888 \\
\text { Sig=,023a } \\
\text { 1. Sinıf ile uzatmalı } \\
\text { ögrenciler }\end{array}$} \\
\hline & & 2. Sinif & 45 & 3,3662 &, 72850 & \\
\hline & & Uzatmalı & 11 & 3,0079 & ,93328 & \\
\hline & & Toplam & 117 & 3,4890 & ,83347 & \\
\hline \multirow{4}{*}{ Bilişsel öğe } & & 1. Sinif & 61 & 3,8074 & 81444 & \multirow{4}{*}{$\begin{array}{r}\mathrm{F}=3,121 \\
\mathrm{Sig}=, \mathbf{0 4 8} \\
\text { 1. sinıf ile uzatmalı } \\
\text { ögrenciler }\end{array}$} \\
\hline & & 2. Sinif & 45 & 3,5472 & ,68116 & \\
\hline & & Uzatmalı & 11 & 3,2500 & 90312 & \\
\hline & & Toplam & 117 & 3,6549 & $\overline{, 78846}$ & \\
\hline \multirow{4}{*}{ Duyuşsal öğe } & & 1. Sinıf & 61 & 3,6206 & 97446 & \multirow{4}{*}{$\begin{array}{r}\mathrm{F}=3,192 \\
\text { Sig=,045 a } \\
\text { Uzatmalı ile 1. Sinıf } \\
\text { ögrrenciler }\end{array}$} \\
\hline & & 2. Sinif & 45 & 3,3460 & ,90478 & \\
\hline & & Uzatmalı & 11 & 2,8831 & 1,02383 & \\
\hline & & Toplam & 117 & 3,4457 & 97057 & \\
\hline \multirow{4}{*}{ Davranışsal öğe } & & 1. Sinif & 61 & 3,5656 & ,93419 & \multirow{4}{*}{$\begin{array}{r}\mathrm{F}=3,528 \\
\text { Sig=,033a } \\
\text { Uzatmalı ile 1. Sınıf } \\
\text { ögrenciler }\end{array}$} \\
\hline & & 2. Sinif & 45 & 3,2028 & 90150 & \\
\hline & & Uzatmalı & 11 & 2,8750 & 1,15380 & \\
\hline & & Toplam & 117 & 3,3611 & ,96361 & \\
\hline \multirow{4}{*}{ Meslek tercihi } & & 1. Sinif & 61 & 3,7377 & 1,31672 & \multirow{4}{*}{$\begin{array}{r}\mathrm{F}=3,539 \\
\text { Sig=,032 } \\
\text { Uzatmalı ile 1. Sinıf } \\
\text { ögrenciler }\end{array}$} \\
\hline & & 2. Sinif & 45 & 3,2148 & 1,07110 & \\
\hline & & Uzatmalı & 11 & 2,9394 & 1,13351 & \\
\hline & & Toplam & 117 & 3,4615 & 1,23785 & \\
\hline $\begin{array}{c}\text { Tutum, Tutum Öğgeleri } \\
\text { ve Meslek Tercihi }\end{array}$ & & Değişkenler & $\mathbf{N}$ & Ort. & $\begin{array}{l}\text { Standart } \\
\text { Sapma }\end{array}$ & $\begin{array}{c}\text { F ve Sig. (Farkın } \\
\text { kaynağı) }\end{array}$ \\
\hline \multirow{2}{*}{ Duyuşsal öğe } & \multirow{2}{*}{ : } & Normal Öğretim & 81 & 3,5732 & ,90082 & \multirow{2}{*}{ Sig. $(2$-tailed $)=, 032$} \\
\hline & & İkinci Öğretim & 36 & 3,1587 & 1,07001 & \\
\hline \multirow{2}{*}{ Duyuşsal öğe } & \multirow{6}{*}{ 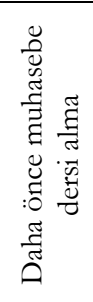 } & Evet & 31 & 3,7281 & ,69630 & \multirow{2}{*}{ Sig. $(2$-tailed $)=, 025$} \\
\hline & & Hayır & 86 & 3,3439 & 1,03675 & \\
\hline \multirow{2}{*}{ Davranışsal öğe } & & Evet & 31 & 3,7661 &, 70100 & \multirow{2}{*}{ Sig. $(2$-tailed $)=, 006$} \\
\hline & & Hayır & 86 & 3,2151 & 1,00617 & \\
\hline \multirow{2}{*}{ Genel Tutum } & & Evet & 31 & 3,7630 &, 59897 & \multirow{2}{*}{ Sig. (2-tailed) $=, 011$} \\
\hline & & Hayır & 86 & 3,3903 & 88553 & \\
\hline
\end{tabular}




\begin{tabular}{|c|c|c|c|c|c|c|}
\hline \multirow{2}{*}{ Bilişsel öğe } & \multirow{8}{*}{ 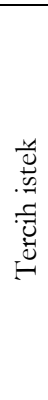 } & Evet & 80 & 3,7703 & 83733 & \multirow{2}{*}{ Sig. $(2$-tailed $)=, 009$} \\
\hline & & Hayır & 37 & 3,4054 & ,60911 & \\
\hline \multirow{2}{*}{ Duyuşsal öğe } & & Evet & 80 & 3,5964 & ,97892 & \multirow{2}{*}{ Sig. $(2$-tailed $)=, 010$} \\
\hline & & Hayır & 37 & 3,1197 & 87903 & \\
\hline \multirow{2}{*}{ Davranışsal öğe } & & Evet & 80 & 3,5000 & ,95156 & \multirow{2}{*}{ Sig. $(2$-tailed $)=, 021$} \\
\hline & & Hayır & 37 & 3,0608 & ,93245 & \\
\hline \multirow{2}{*}{ Genel Tutum } & & Evet & 80 & 3,6234 &, 86365 & \multirow{2}{*}{ Sig. (2-tailed) $=, 005$} \\
\hline & & Hayır & 37 & 3,1986 & ,68902 & \\
\hline
\end{tabular}

Sig. $0.05-{ }^{a}$ Bonferroni, ${ }^{b}$ Tambane

Tablo 4'te yar alan analiz sonuçlarına göre Sig. Değeri 0,05'ten küçük olan değişkenlerde istatistiki olarak anlamlı fark bulgulanmıştır. Öğrencilerin okuduğu sınıf ve genel tutum, bilişsel öğe, duyuşsal öğe, davranışsal öğe ve meslek tercihi değişkenleri arasında istatistiki olarak anlamlı farklılık vardır. Bu farklıık her grup için 1. sınıf öğrencileri ve uzatmalı öğrenciler arasındadır. 1. sınıf öğrencilerinin muhasebe derslerine yönelik tutumu uzatmalı öğrencilere kıyasla olumlu yönde daha yüksektir. Tablo 4'te yer alan ortalamalar incelendiğinde muhasebe derslerine yönelik tutum ve öğrencinin okuduğu sınıf ters orantılıdır. Öğrencinin okuduğu yil sayısı arttıkça muhasebe derslerine olan olumlu tutum ortalaması azalmaktadır. Benzer şekilde ögrencinin okuduğu yıl sayısı arttıkça muhasebeyi meslek olarak yapma isteği ortalamaları azalmaktadır.

Normal öğretim ve ikinci öğretim öğrencileri ve muhasebe derslerine yönelik tutum analiz edildiğinde yalnızca tutumun duyuşsal öğe boyutunda arasında istatistiki olarak anlamlı farklılık bulgulanmıştır. Normal öğretim öğrencilerinin duyuşsal öğe ortalamaları ikinci öğretim öğrencilerine göre daha yüksektir. Diğer değişkenler arasında istatistiki olarak anlamlı farklılık yoktur.

Muhasebe ve Vergi Bölümünden önce muhasebe dersi alan öğrenciler ve muhasebe derslerine yönelik tutum analiz edildiğinde duyuşsal öğe, davranışsal öğe ve genel tutum ile daha önce muhasebe dersi alma değişkenleri arasında istatistiki olarak anlamlı farklılık bulgulanmıştır. Daha önce muhasebe dersi almış olan öğrencilerin muhasebe derslerine yönelik tutumları ortalamaları daha yüksektir.

Muhasebe ve Vergi Bölümünü tercih etme istekliliği ve muhasebe derslerine yönelik tutum analiz edildiğinde genel tutum, bilişsel öğe, duyuşsal öğe ve davranışsal öğe ile tercih etme istekliliği değişkenleri arasında istatistiki olarak anlamlı farkllık bulgulanmıştır. Okuduğu bölümü isteyerek tercih eden öğrencilerin muhasebe derslerine yönelik genel tutum ve tutum alt boyutları ortalamaları daha yüksektir.

Cinsiyet, öğrencinin mezun olduğu lise türü ve muhasebe derslerine yönelik tutum arasında istatistiki olarak anlamlı bir fark bulunmamıştır. Öğrencilerin çalışma durumu, muhasebe alanında çalısma durumu ile tutum arasında istatistiki olarak anlamlı farklılık bulunmamaktadır. Ayrıca demografik özellikler ile muhasebe meslek tercihi arasında -öğrencinin okuduğu sınıf hariç- istatistiki olarak anlamlı farklılık bulunmamaktadır.

\section{SONUÇ}

Öğrencilerin muhasebe derslerine yönelik tutumları, muhasebe ile ilk kez karşılaştıkları derslerde şekillenmektedir. Bu derslerdeki “öğretici” faktörü başta olmak üzere fiziksel imkânlar, ders öğretim yöntemleri ve materyalleri gibi faktörler öğrencilerin muhasebe derslerine yönelik tutumlarını etkilemektedir. Öğrencilerin muhasebe derslerine yönelik olumsuz tutumunun değiştirilebilmesi için muhasebe derslerine yönelik tutumun ölçülmesi ve olumsuz tutuma neden olan faktörler için çözümlerin geliştirilmesi gerekmektir.

Çalışmada Aksaray Üniversitesi, Sosyal Bilimler Meslek Yüksekokulu, Muhasebe ve Vergi Uygulamaları Bölümü ögrencilerinin muhasebe derslerine yönelik tutumları incelenmektedir. Araştırmaya katılan ön lisans öğrencilerinin muhasebe derslerine yönelik tutumlarının ortalamasının olumlu yönde ortanın üzerinde olduğu görülmektedir. Muhasebeye yönelik genel olumsuz tutumun tersine bulgulanan olumlu tutum literatürdeki benzer çalışmalarla (Aygün \& Gerekan, 2012; Kandemir, Kardeş, \& Baykut, 2016; Costa, Gomes, Rosa, \& Batalhone, 2015; Utku \& Erol, 2015) paralellik göstermektedir. Demografik özelliklere ilişkin gerçekleştirilen fark testlerinin sonuçlarına göre öğrencilerin okuduğu sınıfa göre muhasebe derslerine yönelik tutumları farklılaşmaktadır. Bu bulgu Coşkun vd.'nin (2017) çalışmalarındaki bulguları destekler niteliktedir. Ayrıca daha önce muhasebe eğitimi alan öğrencilerin muhasebe derslerine yönelik tutumunun daha olumlu olması Çakır vd.'nin (2014) çalışmalarındaki bulgularla paralellik göstermektedir. Çalışmada 
cinsiyet, mezun olunan lise türü ve muhasebe derslerine yönelik tutum değişkenleri arasında istatistiki olarak anlamlı fark bulunamamıştır. Bu bulgu Aksu \& Oral'n (2017) çalışmasındaki bulgulardan farklı olmakla birlikte; Coşkun vd.'yi (2017) destekler niteliktedir. Ayrıca okuduğu bölümü isteyerek tercih eden öğrencilerin muhasebe derslerine yönelik genel tutum ve tutum alt boyutları ortalamaları olumlu yönde daha yüksek tespit edilmiştir.

Araştırma sonucunda elde edilen bir diğer önemli bulgu, öğrencilerin okuduğu yıl sayısı arttıkça muhasebe derslerine yönelik tutum ortalamalarında düşüş olmaktadır. Bu bulgu bazı çalışmalarla (Geiger \& Ogilby, 2000; Marriott \& Marriott, 2003; Góis \& Brás, 2013) benzerlik göstermektedir. Bu noktada muhasebe derslerine yönelik tutumda en önemli unsur olan öğreticilere öğrencilerin muhasebe derslerine tutumlarının olumlu yönde geliştirilebilmesi sürecine destek konusunda sorumluluk düşmektedir.

Tutumun üç boyutu olan "Bilişsel öğe, Duyuşsal öğe ve Davranışsal öğe” ve öğrencilerin muhasebeye yönelik tutumu ele alındığında, genel olarak öğrenciler gelecekte muhasebenin sunduğu potansiyel firsatların farkında oldukları ve muhasebe açısından gelişime hazır olduklarını söylemek mümkündür. Ancak öğrenciler muhasebe alanında iddialı olmadıklarını ve muhasebe bilgisi edinirken kaygılı olduklarını ve sıkıldıklarını belirtmektedirler. $\mathrm{Bu}$ kapsamda derslerin veriliş biçimleri, kullanılan materyaller ve kariyer firsatlarının aktarılması ile ilgili çeşitli geliştirmelerle öğrencilere daha yararlı olunabileceğini söylemek mümkündür.

Gelecek araştırmalarda öğrenciler, meslek mensupları ve öğreticileri kapsayan farklı grupların aynı araştırmada bir araya gelmeleri sağlanarak muhasebe mesleğine yönelik tutum kapsamında ihtiyaçlar/beklentiler ve çözüm önerileri üzerine nicel ve nitel araştırmalar gerçekleştirilebilir.

\section{KAYNAKÇA}

Akpınar, S., \& Yıldız, Ş. (2018). Muhasebe Eğitimi Alan Öğrencilerin Muhasebe Alg1larına Yönelik Metaforlar. Mubasebe ve Finansman Dergisi, Ocak, 91-114.

Aksu, İ., \& Oral, T. (2017). Lisans Öğrencilerinin Muhasebe Dersine Yönelik Alg1 Tutum Ve Başar1 Durumlarına İlişkin Bir Araştırma. Journal Of Social And Humanities Sciences Research, 4(12), 706-717.

Aygün, D., \& Gerekan, B. (2012). Muhasebe Dersini İlk Defa Alan Öğrencilerin Derse Yönelik Algilarının Tespiti: Karşılaştırmalı Bir Alan Araştırması. Yönetim ve Ekonomi Araştırmalar Dergisi(18).

Byrne, D. M., \& Willis, P. (2005). Irish secondary students' perceptions of the work of an accountant and the accounting profession. Accounting Education: an International Journal, 14(4), 367-381.

Costa, P. d., Gomes, G. d., Rosa, N., \& Batalhone, P. P. (2015). An Analysis of Student Perceptions of Introductory Accounting Classes. International Journal of Advances in Management and Economics, 4(4), 39-56.

Coşkun, S., Kır, A., \& Özbay, F. (2017). Meslek Yüksekokulu Muhasebe Bölümü Öğrencilerinin Muhasebe Eğitimine Bakış Açılarının Ve Mesleki Eğitimden Beklentilerinin Değerlendirilmesi. Uluslararası Yönetim İktisat ve İsletme Dergisi, Özel Sayl, 314-329.

Çakır, N., Canbaz, S., \& Gümüş, S. (2014). Meslek Yüksekokulu Öğrencilerinin Muhasebe Eğitimindeki Alg1 ve Beklentilerinin Belirlenmesine Yönelik Bir Araştırma: Uzunköprü MYO Örneği. Uluslararası Hakemli Paz̧arlama Ve Pazar Arastermalarn Dergisi, 2(1).

Çelik, M., \& Serinkan, C. (2011). Muhasebe Dersine Yönelik Tutumlarda Üniversite Öğrencilerinin Bireysel ve Bölümsel Farkl11ıkları. MÖDAV(3), 289-321.

Ertuğrul, İ., \& Özdemir, S. (2014). Muhasebe Dersi Alan Ön Lisans Ve Lisans Öğrencilerinin Derse Yönelik Tutumlarının Tespiti: Ege Bölgesinde Bir Uygulama. Niğde Üniversitesi İiBF Dergisi, 7(1), 204-214.

Geiger, M. A., \& Ogilby, S. M. (2000). The first course in accounting: students' perceptions and their effect on the decision to major in accounting. Journal of Accounting Education, 18, 63-78.

George, D., \& Mallery, P. (2010). SPSS for Windows Step by Step: A Simple Guide and Reference (10th Edition b.). Boston: Pearson. 
Apak I.

Góis, C., \& Brás, F. A. (2013). In the aftermath of the Bologna process: exploring the master students' perceptions on accounting in two portuguese higher education institutions. The Spanish Journal of Accounting, Finance and Management Education, 4, 34-55.

Gör, Y. (2017). Farklı Eğitim Programlarındaki Öğrencilerin Finansal Muhasebe Dersine İlişkin Alg1larına Yönelik Bir Uygulama: Çankın Örneği. Uluslararası Yönetim İktisat ve İsletme Dergisi, Özel Sayı, 369-380.

Gravetter, F., \& Wallnau, L. (2014). Essentials of statistics for the behavioral sciences (8th Edition b.). Belmont: CA:Wadsworth.

https://obs.aksaray.edu.tr/oibs/bologna. (2019, 10 21). https://obs.aksaray.edu.tr/oibs/bologna: https://obs.aksaray.edu.tr/oibs/bologna/start.aspx?gkm=074038800355053445636690377563440433342 214635485355753333631120 adresinden alınd 1

Kandemir, T., Kardeş, Z., \& Baykut, E. (2016). Meslek Yüksekokulu Öğrencilerinin Muhasebe Eğitimine Bakış Açıları: Afyon Kocatepe Üniversitesi Meslek Yüksekokulları Örneği. Afyon Kocatepe Üniversitesi Sosyal Bilimler Dergisi, 18(2), 133-151.

Kızıl, C., \& Gencer, K. (2016). Muhasebe Dersi Alan Öğrencilerin Başarısına Etki Eden Faktörlerin Tespiti: Yalova Üniversitesi'nde Bir Uygulama. Siyasal Bilgiler Fakültesi Dergisi, 1(2), 67-110.

Kutlu, H. A., \& Öztürk, S. (2018). Basic Factors That Affect The Students Attitudes Towards Accounting Courses: A Research. Journal of Research in Business, 3(1), 9-30.

Loewenthal, K. M. (2004). An introduction to psychological tests and scales (2nd Edition b.). Hove: UK: Psychology Press.

Malthus, S., \& Fowler, C. (2009). Perceptions of accounting: a qualitative New Zealand study. Pacific Accounting Review, 21(1), 26-47.

Marriott, P., \& Marriott, N. (2003). Are we turning them on? A longitudinal study of undergraduate accounting students' attitudes towards accounting as a profession. Accounting Education, 12(2), 113-133.

Tuğay, O. (2014). Muhasebe Dersi Alan Öğrencilerin Muhasebe Dersine Yönelik Algıları ve Muhasebe Öğretim Elemanlarından Beklentileri Üzerine Mehmet Akif Ersoy Üniversitesinde Bir Araştırma. Eskişehir Osmangazi Üniversitesi İBF Dergisi, Aralk, 49-68.

Utku, B. D., \& Erol, İ. (2015). Lisans Öğrencilerinin Muhasebeye Giriş Dersine Yönelik Algılamalarının Belirlenmesi. Journal of Accounting, Finance and Auditing Studies, 1(3), 91-104.

Wells, P. K. (2015). New Zealand High School Students' Perception of Accounting: How and Why Those Perceptions Were Formed. Accounting Education: an international journal, 24(6), 461-479. 